\title{
Stability of Enzymes in Starving Arthrobacter crystallopoietes
}

\author{
By R. MEGANATHAN* AND J. C. ENSIGN \\ Department of Bacteriology, University of Wisconsin, Madison, Wisconsin, U.S.A.
}

(Received I 2 August I975; revised I November 1975)

\section{SUMM A R Y}

Cell-free extracts prepared from spherical and rod-shaped cells of Arthrobacter crystallopoietes were assayed for enzymes during various periods of starvation. The level of NADH oxidase dropped to 20 and $30 \%$, respectively, in spherical and rod-shaped cells during the first $\mathrm{I}$ to 2 days of starvation and then remained constant for 9 days. Catalase activity decreased continuously and reached a low level in 9 days. Enzymes involved in glucose metabolism and the tricarboxylic acid cycle were stable for the duration of the experiment (about I week). Succinic dehydrogenase, fumarase and aconitase were stable during 2 I days of starvation, which is the longest time enzymes have been shown to be stable in any bacterium under conditions of total starvation.

\section{INTRODUCTION}

The genus Arthrobacter has been reported to be the most widespread and abundant micro-organism in soil (Gounot, 1967; Mulder, 1963; Mulder \& Antheunisse, 1963), and highly resistant to starvation (Boylen \& Ensign, 1970 $a$; Zevenhuizen, I966) and desiccation (Boylen, 1973). When starved, Arthrobacter crystallopoietes maintains $100 \%$ viability for 30 days. In general, there is a lack of physiological studies on starving bacteria and few reports on the stability of enzymes during starvation. Since an organism able to maintain essential enzymes during starvation will be better adapted for surviving adverse conditions than its counterpart unable to do so, studies were undertaken to determine the stability of various enzymes in a starvation-resistant organism, A. crystallopoietes. A preliminary report of these findings has appeared (Meganathan \& Ensign, 1972).

\section{METHODS}

Growth conditions. Arthrobacter crystallopoietes (ATCCI5481) was grown in the minimal salts medium of Boylen \& Ensign (1970a). For growing cells in the form of spheres the medium was supplemented with $0.5 \%$ glucose, and for rods glucose was replaced by $0.5 \%$ ammonium succinate. Glucose and succinate were sterilized separately. About 50 to $100 \mathrm{ml}$ of glucose-grown cells were inoculated into 0.5 to 11 of glucose or succinate media and grown to about $200 \mathrm{Klett}$ units. This cell density corresponds to a dry weight of $0.5 \mathrm{mg} \mathrm{ml}^{-1}$ and approximately $\mathrm{I}^{9} \mathrm{cells} \mathrm{ml}^{-1}$ (Petroff-Hauser counts) for spheres, and $\mathrm{I} \cdot 0 \mathrm{mg} \mathrm{ml}{ }^{-1}$ and $2.5 \times 10^{8}$ cells $\mathrm{ml}^{-1}$ for rods.

Starvation conditions. Bacteria (spheres (cocci) or rods) were harvested by centrifuging at $4000 \mathrm{~g}$ for 5 to $10 \mathrm{~min}$ at 2 to $4{ }^{\circ} \mathrm{C}$. The bacteria were washed twice with an approximately equal volume of $0.03 \mathrm{M}$-potassium phosphate buffer $\mathrm{pH} 7.0$, by centrifugation and resuspension. The bacteria were suspended in buffer at room temperature and starved by incubating

* Present address: Department of Biological Sciences, Duquesne University, Pittsburgh, Pennsylvania 15219 , U.S.A. 
at $30{ }^{\circ} \mathrm{C}$ with shaking. No change in viability was observed for the duration of the experiments.

Preparation of cell-free extracts. Samples were withdrawn at various times during starvation, centrifuged and kept frozen. The bacteria were suspended in $0.03 \mathrm{M}$-phosphate buffer $\mathrm{pH} 7{ }^{\circ} \mathrm{O}$ and extracts used for the assay of NADH oxidase and catalase were prepared either by sonication or by grinding with aluminium oxide. For tricarboxylic acid (TCA) cycle enzymes, extracts were prepared by grinding with aluminium oxide. Bacteria for preparing the extracts used in assaying enzymes of glucose catabolism were washed in $0.02 \mathrm{M}$-tris- $\mathrm{HCl}$ buffer, $\mathrm{pH} \mathrm{7.4}$, suspended in the same buffer, and passed through a cold French pressure cell twice at $4 \mathrm{I}$ to $48 \mathrm{MPa}$. During the preparation of extracts, care was taken to maintain the temperature below $5{ }^{\circ} \mathrm{C}$. The extracts were centrifuged at $3000 \mathrm{~g}$ for $5 \mathrm{~min}$ and the supernatant was further centrifuged at $17000 \mathrm{~g}$ for $15 \mathrm{~min}$. The clear supernatant was used in all enzyme assays.

Preparation of toluenized cells. After various times of starvation, $8 \mathrm{ml}$ of bacteria were centrifuged and suspended in $0.8 \mathrm{ml}$ of $0.03 \mathrm{M}$-potassium phosphate buffer $\mathrm{pH} 7 \cdot 0$. After adding 2 drops of toluene, the tubes were shaken at $30^{\circ} \mathrm{C}$ for $30 \mathrm{~min}, 0.5 \mathrm{ml}$ of the toluenized bacteria was mixed with $0.5 \mathrm{ml}$ of 0.03 M-potassium phosphate buffer $\mathrm{pH} 7.0$, and $0.1 \mathrm{ml}$ of this suspension was used in enzyme assays.

Protein determination. The procedure of Sutherland et al. (1949) was used, with bovine serum albumin as the standard.

Units of enzyme activity. The activities of NADH oxidase and catalase were calculated as $\triangle E \min ^{-1}$ (mg protein) ${ }^{-1}$. The activity of the zero time sample was taken as 100 and the activities are expressed as the percentage of the initial activity. All the other activities are expressed as $\mathrm{nmol} \mathrm{min}^{-1}$ (mg protein) ${ }^{-1}$.

Enzyme assays. The assays were done spectrophotometrically at room temperature using a Cary 15 recording spectrophotometer. NADH oxidase was assayed in a volume of $1.0 \mathrm{ml}$, and all the other assays in a volume of $3.0 \mathrm{ml}$.

NADH oxidase. NADH oxidation was measured at $340 \mathrm{~nm}$ according to the method of Mackler \& Green (1956).

Catalase was measured spectrophotometrically as decrease in extinction at $240 \mathrm{~nm}$ (Bergmeyer, 1965).

Aconitase [Citrate (isocitrate) hydro-lyase, EC.4.2.I.3]. The conversion of isocitrate to cis-aconitate was measured as increase in extinction at $240 \mathrm{~nm}$ (Racker, 1950). The molar extinction coefficient was taken as $3.3 \times 10^{3} 1 \mathrm{~mol}^{-1} \mathrm{~cm}^{-1}$ (Mahler, Wittenberger \& Brand, 1958).

Isocitrate dehydrogenase (threo- $\mathrm{D}_{\mathrm{B}}$-isocitrate:NADP+ ${ }^{+}$oxidoreductase, EC. I.I.I.42). The isocitrate-dependent reduction of NADP was measured at $340 \mathrm{~nm}$ (Ochoa, 1955). NADP was omitted from the blank. Since the reaction slows down quickly, all components except the enzyme were mixed first, and after mixing in the enzyme, recording was started immediately. Enzyme activity was calculated from the initial rate. The molar extinction coefficient of NADPH was taken as $6 \cdot 22 \times 10^{3} 1 \mathrm{~mol}^{-1} \mathrm{~cm}^{-1}$.

Succinate dehydrogenase [Succinate:(acceptor) oxidoreductase, EC. I.3.99. I]. The procedure of Owen \& Freer (I970), based on the method of Ells (1959), was used. Substrate was omitted from the blank. The position of the cuvettes was reversed (i.e. the experimental compartment contained the blank and the blank compartment contained the experimental cuvette) and the increase in extinction was recorded at $600 \mathrm{~nm}$. The molar extinction coefficient for the reduction of dichlorophenolindophenol (DCIP) was taken as $1 \cdot 61 \times 10^{4}$ $1 \mathrm{~mol}^{-1} \mathrm{~cm}^{-1}$ (Rutberg \& Hoch, 1970). 
Fumarase (L-malate hydro-lyase, EC. 4.2.I .2). The reduction of malate to fumarate was followed at $240 \mathrm{~nm}$ (Hanson \& Cox, 1967). Substrate was omitted from the blank. The molar extinction coefficient for fumarate was taken to be $2.4 \times 10^{3} 1 \mathrm{~mol}^{-1} \mathrm{~cm}^{-1}$ (Bock \& Alberty, 1953).

Malate dehydrogenase (L-malate:oxygen oxidoreductase, EC. I.I.3.3). The flavinlinked malate dehydrogenase was assayed according to Phizackerley (1969) except that $\mathrm{KCN}$ was added to the reaction mixture (Francis et al., 1963). The position of the cuvettes was reversed and the reduction of DCIP was measured at $600 \mathrm{~nm}$.

Aldolase (fructose 1,6-diphosphate D-glyceraldehyde 3-phosphate lyase, EC. 4-I.2.13). The experimental cuvette contained $66.7 \mathrm{~mm}$-tris- $\mathrm{HCl}$ buffer, $\mathrm{pH} 8, \mathrm{IO0} \mathrm{mm}-\mathrm{KCl}$, I mMdithiothreitol, $0.156 \mathrm{~mm}-\mathrm{NADH}, 2.5 \mathrm{~mm}$-fructose $\mathrm{I}$,6-diphosphate, triose phosphate isomerase and $\alpha$-glycerophosphate dehydrogenase in excess units, and extract. To correct for the NADH oxidase present in the extract, NADH was added to both the blank and the experimental cuvette. The blank lacked substrate. The positions of the cuvettes were reversed and the increase in extinction was recorded at $340 \mathrm{~nm}$.

Phosphohexose isomerase (D-glucose 6-phosphate ketol-isomerase, EC. 5.3.1.9). The method of Gale \& Beck (1967) was used. Substrate was omitted from the blank.

Fructose diphosphatase (D-fructose 1,6-diphosphate I-phosphohydrolase, EC. 3 I I 3 I I). The procedure resembled that for phosphohexose isomerase; fructose 6-phosphate was replaced by fructose I,6-diphosphate.

Glucose 6-phosphate dehydrogenase (D-glucose 6-phosphate:NADP ${ }^{+}$oxidoreductase, EC. I.I.I.49). The procedure was based on that for phosphohexose isomerase; glucose 6-phosphate dehydrogenase was omitted and fructose 6-phosphate was replaced by glucose 6-phosphate.

6-Phosphogluconate dehydrogenase (6-phospho-D-gluconate:NADP+ oxidoreductase, EC. I.I.I.43). The procedure was the same as for glucose 6-phosphate dehydrogenase except that glucose 6-phosphate was replaced by gluconate 6-phosphate.

\section{RESULTS}

\section{Enzyme stability}

Stability of NADH oxidase. The levels of NADH oxidase in both spherical and rodshaped cells during various times of starvation are shown in Fig. $\mathbf{I}$.

Stability of catalase. Catalase activity in spherical cells decreased progressively up to nine days and reached a very low level (Fig. 2). In rod-shaped cells, activity decreased but the level was always higher than in spherical cells.

Stability of glucose metabolic enzymes. Two enzymes of the hexose monophosphate pathway (glucose 6-phosphate dehydrogenase and 6-phosphogluconate dehydrogenase), two enzymes of glycolysis (phosphohexose isomerase and aldolase), and one enzyme involved in gluconeogenesis (fructose diphosphatase) were assayed during starvation for up to a week (Table 1 ). The activities increased for the first two to three days and then remained constant for the rest of the experiment.

Stability of TCA cycle enzymes. Aconitase, isocitrate dehydrogenase, succinate dehydrogenase, fumarase and malate dehydrogenase were stable during starvation for about a week in extracts of spherical and rod-shaped cells (Table 2). Rod-shaped cells had more enzymic activity than spherical cells. There was an initial increase in the specific activities of all the enzymes in both spheres and rods. The effect of prolonged starvation on three TCA cycle enzymes, succinate dehydrogenase, fumarase and aconitase, was studied during 2 I days of 


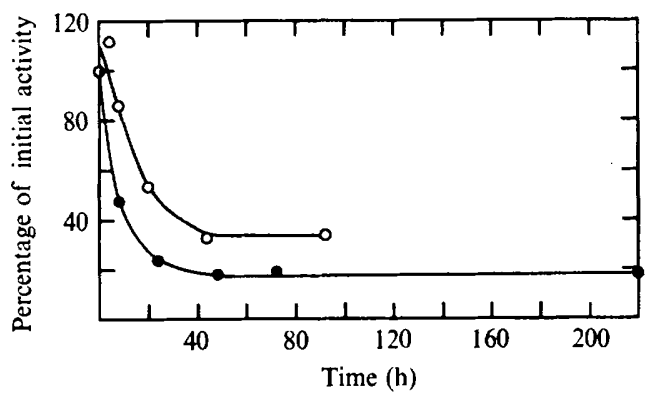

Fig. I

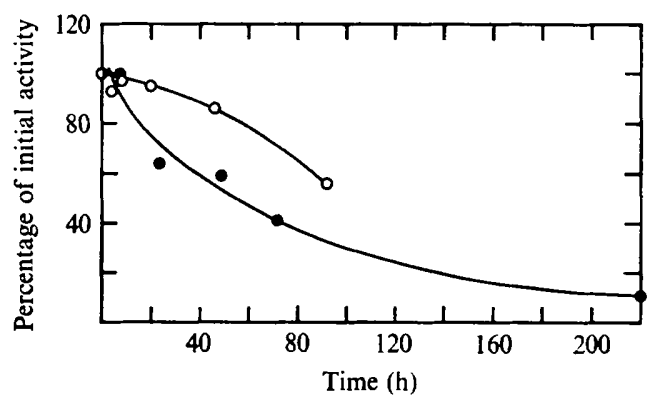

Fig. 2

Fig. I. NADH oxidase activity in spherical and rod-shaped cells of $A$. cystallopoietes during various times of starvation. Activity in spheres (O) and rods $(O)$.

Fig. 2. Catalase activity in spherical and rod-shaped cells of $A$. crystallopoietes during various times of starvation. Activity in spheres $(O)$ and rods $(O)$.

\section{Table I. Effect of starvation on glucose metabolic enzymes in cocci}

All activities are given as nmol of product formed/min per $\mathrm{mg}$ protein, and aldolase as $\mathrm{nmol}$ of substrate used/min per mg protein. G-6-P DH, glucose 6-phosphate dehydrogenase; 6-P-G DH, 6-phosphogluconate dehydrogenase; PHI phosphohexose isomerase; FDP, fructose diphosphatase.

$\begin{array}{cccccc}\text { Starvation time (h) } & \text { G-6-P DH } & \text { 6-P-G DH } & \text { PHI } & \text { FDP } & \text { Aldolase } \\ 0 & 8 \cdot 4 & 53 & 222 & 4 \cdot 4 & \text { 195 } \\ 19 & 10 \cdot 0 & 67 & 285 & 5 \cdot 8 & \text { 167 } \\ 47 & 9 \cdot 7 & 49 & 327 & 4 \cdot 2 & 209 \\ 125 & 9 \cdot 3 & 50 & 253 & 6 \cdot 0 & 213 \\ 173 & 7 \cdot 1 & 38 & 266 & 5 \cdot 0 & 221\end{array}$

Table 2. Effect of starvation on TCA cycle enzymes in cocci and rods

All activities are given as $\mathrm{nmol}$ of product formed/min per $\mathrm{mg}$ protein. IDH, isocitrate dehydrogenase; $\mathrm{SDH}$, succinate dehydrogenase; $\mathrm{MDH}$, malate dehydrogenase.

\begin{tabular}{|c|c|c|c|c|c|c|c|c|c|c|}
\hline \multirow{2}{*}{$\begin{array}{l}\text { Starvation } \\
\text { time } \\
\text { (h) }\end{array}$} & \multicolumn{2}{|c|}{ Aconitase } & \multicolumn{2}{|c|}{ IDH } & \multicolumn{2}{|c|}{ SDH } & \multicolumn{2}{|c|}{ Fumarase } & \multicolumn{2}{|c|}{ MDH } \\
\hline & Cocci & Rod & Cocci & Rod & Cocci & Rod & Cocci & Rod & Cocci & Rod \\
\hline 0 & I 50 & 442 & 219 & 390 & 26 & $5 \mathrm{I}$ & I 37 & 729 & 80 & 213 \\
\hline I 7 & 242 & 550 & 264 & 516 & 32 & 70 & 264 & $81 I$ & 88 & 224 \\
\hline $4 \mathrm{I}$ & - & 560 & 一 & 488 & 一 & 80 & - & 753 & 一 & 254 \\
\hline 45 & 223 & 一 & 284 & - & 43 & 一 & 240 & - & 108 & 一 \\
\hline 89 & 219 & $62 \mathrm{I}$ & 310 & 572 & 44 & 87 & 285 & 948 & 104 & 227 \\
\hline I6I & I4I & 427 & 292 & 562 & 37 & 86 & I 72 & 701 & 108 & 216 \\
\hline
\end{tabular}

starvation (Fig. 3). After an initial increase, which varied between enzymes, the activities of succinate dehydrogenase and fumarase remained constant. There was a slight decrease in the activity of aconitase, possibly due to instability of the enzyme during preparative procedures.

\section{Enzyme activity in toluenized cells}

To determine whether the initial increase in specific activity (activity/min per mg protein) was due to new enzyme synthesis or to the selective degradation of proteins (nonenzymic and certain enzymic proteins) resulting in an apparent increase in specific activity 


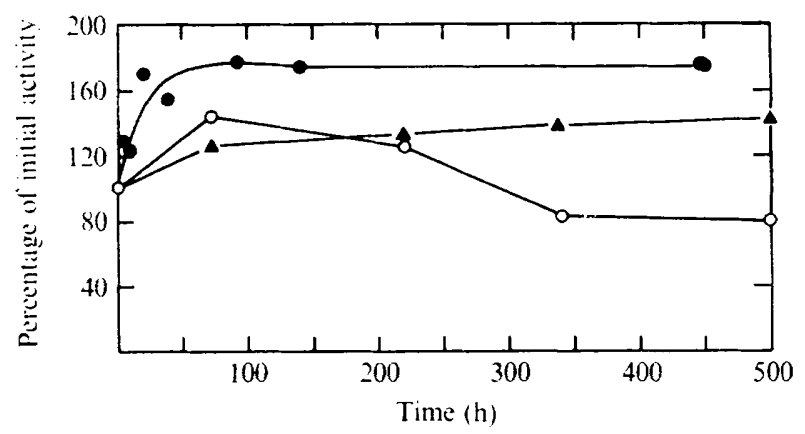

Fig. 3. Succinic dehydrogenase, fumarase and aconitase activities during prolonged starvation of rod-shaped cells of $\boldsymbol{A}$. crystallopoietes. Activity of succinic dehydrogenase $(\boldsymbol{\odot})$, fumarase $(\boldsymbol{\Delta})$ and aconitase ( 3 ).

(due to a decrease in total protein but not the enzymic proteins reported here) succinate dehydrogenase and fumarase were assayed in toluene-treated bacteria. There was no increase in activity up to five days, although the same enzymes have shown an increase when assayed in extracts.

\section{DISCUSSION}

The Embden-Meyerhof-Parnas (EMP) and pentose phosphate pathways and TCA cycle operate in A. crystallopoietes (Krulwich \& Ensign, 1969). After an initial rapid decrease in endogenous respiration to a very low level, the rate remained constant for 24 days (Boylen \& Ensign, $1970 b$ ). The stability of selected enzymes representing the above pathways was examined during cell starvation.

Although the starving bacteria possessed high stable levels of TCA cycle enzymes, the ability of whole cells to oxidize succinate is rapidly lost (Boylen \& Ensign, I970 $b$ ). To reconcile this discrepancy, succinate dehydrogenase activity was measured in succinategrown whole cells after various periods of starvation. Succinate-dependent reduction of DCIP was rapidly lost during starvation. As the same cells treated with toluene showed high levels of succinate dehydrogenase, the loss of succinate-oxidizing ability in whole cells during starvation is due to the bacteria becoming impermeable.

There is a consistent increase in the specific activities of the enzymes during the first two days of starvation, which can be brought about either by new enzyme synthesis or by the selective degradation of proteins other than the enzymes studied here. Synthesis of new enzymes in the absence of carbon, nitrogen or energy source seemed improbable. Protein degradation occurs during starvation (Boylen \& Ensign, 1970 b), and during this study when cell extracts were assayed for protein content this showed a tendency to decrease irrespective of the method used for preparing the extracts. During the first two days of starvation, when most enzymes increased in specific activity, three enzymes, NADH oxidase, catalase and 2-hydroxypyridine mono-oxygenase (Boylen \& Ensign, 1970 b) decreased in specific activities. Since specific activities are expressed on the basis of the protein content of extracts, if the quantity of enzyme remains constant and the total protein decreases then an apparent increase in specific activity is to be expected. If the enzymes are assayed in whole cells (made permeable by toluene) and if the activities are expressed on the basis of constant volume, the initial increase in activity would not be seen unless there is new synthesis. This is because the number of molecules of enzymes per unit volume of sample should be the same, since 
the number of bacteria per volume is the same. Succinate dehydrogenase and fumarase were assayed in whole cells made permeable by toluene and the activities were calculated as units/ml culture. Neither enzyme increased in activity during five days of starvation.

Though the TCA cycle enzymes are stable during starvation in both rods and cocci, the levels of enzymes were always higher in growing and starving rods than in cocci. In Pseudomonas aeruginosa, an organism which, like $A$. crystallopoietes, uses TCA intermediates in preference to glucose, the activities of TCA enzymes are about the same in both glucosegrown and succinate-grown cells (Tiwari \& Campbell, 1969). The lower level of TCA enzymes in cocci might be due to the very slow growth of $A$. crystallopoietes on glucose with the consequent decrease in demand for TCA intermediates for biosynthetic purposes.

NADH oxidase activity dropped to 20 and $30 \%$ in cocci and rod-shaped cells respectively and then remained constant; endogenous respiration also decreases (Boylen \& Ensign, I970a).

Boylen \& Ensign (1970b) reported that 2-hydroxypyridine mono-oxygenase, an inducible enzyme of A. crystallopoietes, was completely lost in about two days of starvation. Postgate \& Hunter (1962) studied glycerol dehydrogenase in whole cells of Aerobacter aerogenes during starvation and reported a $50 \%$ loss of activity in $7 \frac{1}{2} \mathrm{~h}$, with a comparable loss in viability. Strange (1966) studied $\beta$-galactosidase in starving Escherichia coli and found a loss of $29 \%$, while there was only a $5 \%$ decrease in viability in $30 \mathrm{~h}$. Willets (1967) reported a $35 \%$ loss in $\beta$-galactosidase activity when $E$. coli was starved of ammonia and leucine for $4 \mathrm{~h}$, while D-serine deaminase and alkaline phosphatase were stable.

In contrast to the above reports, Bentley \& Dawes (1974) reported that starvation of Peptococcus prevotii, an anaerobic bacterium, for $33 \mathrm{~h}$ resulted in complete loss of viability. When the specific activities of enzymes were measured, they found that serine dehydratase and threonine dehydratase showed 32 and $36 \%$ decreases in activity while phosphotransacetylase and acetate kinase activities increased by $\mathrm{I} 6$ and $28 \%$ respectively during this period.

\section{REFERENCES}

Bergmeyer, H. U. (1965). Methods in Enzymatic Analysis, pp. 886-888. New York: Academic Press.

Bentley, C. M. \& DaWes, E. A. (1974). The energy-yielding reactions of Peptococcus prevotii, their behaviour on starvation and the role and regulation of threonine dehydratase. Archives of Microbiology I00, 363-387.

Bock, R. M. \& Alberty, R. A. (1953). Studies on the enzyme fumarase. Kinetics and equilibrium. Journal of the American Chemical Society 75, $1921-1925$.

BOYLEN, C. W. (1973). Survival of Arthrobacter crystallopoietes during prolonged periods of extreme desiccation. Journal of Bacteriology $\mathbf{1 3}, 33-37$.

Boylen, C. W. \& Ensign, J. C. (1970a). Long term starvation survival of rod and spherical cells of Arthrobacter crystallopoietes. Journal of Bacteriology 103, 569-577.

Boylen, C. W. \& ENsign, J. C. (I970 $b$ ). Intracellular substrates for endogenous metabolism during longterm starvation of rod and spherical cells of Arthrobacter crystallopoietes. Journal of Bacteriology 103, $578-587$.

Ells, H. A. (1959). A colorimetric method for the assay of soluble succinic dehydrogenase and pyridine nucleotide-linked dehydrogenases. Archives of Biochemistry and Biophysics 85, 561-562.

Francis, M. J. O., Hughes, D. E., Kornberg, H. L. \& Phizackerley, P. J. R. (I963). The oxidation of L-malate by Pseudomonas sp. Biochemical Journal 89, 430-438.

GALE, N. L. \& BECK, J. V. (I967). Evidence for the Calvin cycle and hexose monophosphate pathway in Thiobacillus ferrooxidans. Journal of Bacteriology 94, $1052-1059$.

Gounot, A. M. (1967). Rôle biologique des Arthrobacter dans les limons souterrains. Annals de l'Institut Pasteur I13, 923-945.

Hanson, R. S. \& Cox, D. P. (1967). Effect of different nutritional conditions on the synthesis of tricarboxylic acid cycle enzymes. Journal of Bacteriology 93, 1777-I787.

KrulWich, T. A. \& ENSIGN, J. C. (I969). Alteration of glucose metabolism of Arthrobacter crystallopoietes by compounds which induce sphere to rod morphogenesis. Journal of Bacteriology $97,526-534$. 
Mackler, B. \& Green, D. E. (1956). Studies on the electron transport system. II. On the 'opening' phenomenon. Biochimica et biophysica acta $2 \mathrm{I}, \mathrm{I}-6$.

MAHLER, H. R., WitTenBerger, M. H. \& Brand, L. (1958). Biochemical studies of the developing avian embryo. II. Enzymes of the citric acid cycle. Journal of Biological Chemistry 233, 770-782.

Meganatran, R. \& Ensign, J. C. (1972). Stability of enzymes in starving Arthrobacter crystallopoietes. In Abstracts of the Annual Meeting of the American Society for Microbiology, p. 45.

Mulder, E. G. (1963). Arthrobacter. In Principles and Applications in Aquatic Microbiology, pp. 254-279. Edited by H. Heukelkian and N. C. Dondero. New York: John Wiley.

Mulder, E. G. \& Antheunisse, J. (1963). Morphologie, physiologie et écologie des Arthrobacter. Annales de l'Institut Pasteur ro5, 46-74.

OсноA, S. (1955). Isocitrate dehydrogenase system (TPN) from pig heart. In Methods in Enzymology, vol. I, pp. 699-700. Edited by S. P. Colowick and N. O. Kaplan. New York: Academic Press.

OWEN, P. \& FreER, J. H. (1970). Factors influencing the activity of succinic dehydrogenase in membrane preparations from Micrococcus lysodeikticus. Biochemical Journal 120, 237-243.

Phizackerley, P. J. R. (1969). Malate dehydrogenase (FAD-linked) from Pseudomonas ovalis Chester. In Methods in Enzymology, vol. 13, pp. 135-140. Edited by S. P. Colowick and N. O. Kaplan. New York: Academic Press.

Postgate, J. R. \& Hunter, J. R. (1962). The survival of starved bacteria. Journal of General Microbiology 29, 233-263.

RACKER, E. (1950). Spectrophotometric measurements of the enzymatic formation of fumaric and cisaconitic acids. Biochimica et biophysica acta 4, $211-214$.

Rutberg, B. \& HосH, J. A. (1970). Citric acid cycle:gene enzyme relationships in Bacillus subtilis. Journal of Bacteriology 104, 826-833.

StranGe, R. E. (I966). Stability of $\beta$-galactosidase in starved Escherichia coli. Nature, London 209, 428-429.

Sutherland, E. W., Cori, C. F., Hynes, R. \& Olson, N. S. (1949). Purification of the hyperglycemicglycogenolytic factor from insulin and from gastric mucosa. Journal of Biological Chemistry 180, 825837 .

Tiwari, N. P. \& Campbell, J. J. R. (1969). Enzymatic control of the metabolic activity of Pseudomonas aeruginosa grown in glucose or succinate media. Biochimica et biophysica acta 192, 395-40I.

WiLleTs, N. S. (1967). Intracellular protein breakdown in non-growing cells of Escherichia coli. Biochemical Journal 103, 453-461.

ZeVenhuizen, L. P. T. M. (1966). Formation and function of the glycogen-like polysaccharide of Arthrobacter. Antonie van Leeuwenhoek 32, 356-372. 